\title{
The Role of Non-Whites in the South African Defence Force
}

\author{
by Cmdt C.J. Nöthling* \\ assisted by Mrs L. Steyn*
}

\section{The early period}

As long ago as 1700, when the Cape of Good Hope was still a small settlement ruled by the Dutch East India Company, Coloureds were subject to the same military duties as Europeans.

It was, however, a foreign war that caused the establishment of the first Pandour regiment in 1781. They comprised a force under white officers that fought against the British prior to the occupation of the Cape in 1795. Between the years 1795-1803 the British employed Coloured soldiers; they became known as the Cape Corps after the second British occupation in 1806. During the first period of British rule Coloured soldiers received a weekly pay of sixpence (sterling) to buy tobacco and were entitled to the same rations and drinks as British troops. During the Anglo-Boer War (1899-1902) Coloureds were used on both sides as drivers, servants and scouts.

At the declaration of War in 1914, military service was extended to include Blacks and Indians. In the South West campaign about 3500 Blacks, Coloureds and Indians were employed in a nonfighting capacity and shortly afterwards a campaign was launched to recruit volunteers for service in East Africa, France and Palestine. During this time requests were received from the Coloured community calling for the establishment of a separate Coloured infantry battalion.

Members of the two Coloured infantry battalions, which rendered active service in Africa and $\mathrm{Pa}$ lestine, were remunerated on the same scales of pay as British infantry soldiers but white personnel were paid in accordance with union rates. During the war members of the Cape Corps distinguished themselves on several occasions, not only in a non-combatant capacity but also as fighting troops.

\section{The Second World War}

In the period between the two World Wars units for Blacks, Coloureds and Indians were nonexistent. It was, however, inevitable that they would be resuscitated when war came in 1939.

As war establishment tables from this period indicate, Non-Whites served as separate units in non-combatant roles such as drivers, stretcherbearers and batmen. However, in some cases the official non-combatant edifice could not be maintained especially as South Africa's shortage of manpower became more acute. This underlined the need for better utilization of Non-Whites in posts listed on the establishment tables of white units and a number of Non-Whites were subsequently attached to combat units and they rendered active service, inter alia in an anti-aircraft role.

The Indian battalion, which was established in 1942, formed part of the Non-European Army Service and as such was entitled and subject to the same conditions of service as Coloureds. In the Indian battalion as well as the Cape Corps, posts up to and including the rank of Warrant Officer (Class 1) could be held by Blacks, Coloureds and Indians.

During the war some 80000 Blacks were recruited into the Native Military Corps for noncombatant duties, such as drivers, messengers, clerks, tailors and medical orderlies. A number of Black auxiliary troops were detailed for special tasks such as the construction of a tunnel in Syria and policing the South African coastline.

\section{A new era: SA Cape Corps}

After disbandment in 1945, the auxiliary services were re-established in 1950. However, the purposeful involvement of South Africa's entire population in the national defence structure after the Second World War may be said to have been initiated in 1963 with the establishment of the SA Cape Corps.

Today Coloured, Indian and Black Permanent Force members, together with their dependents, 


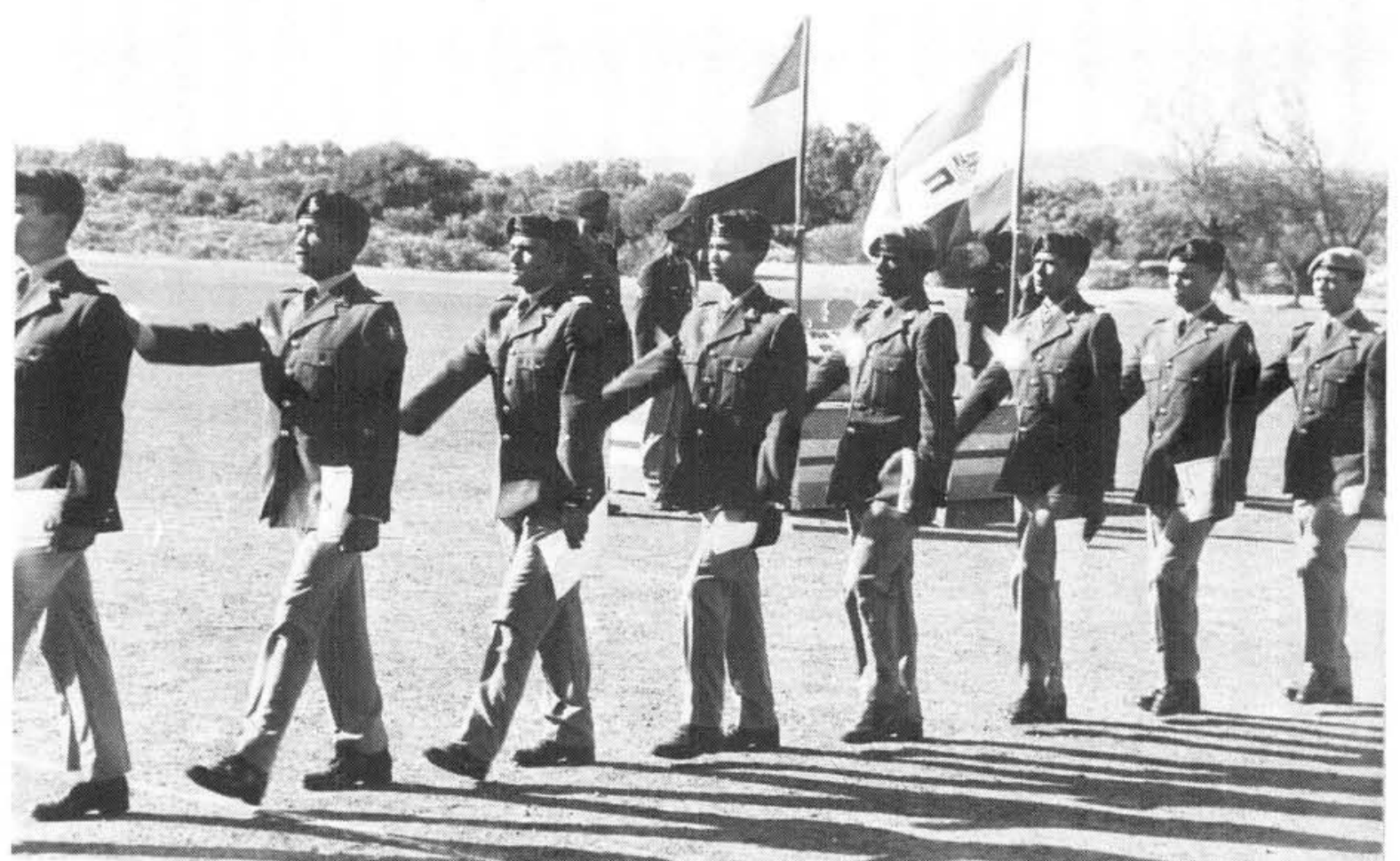

Here the men are going through their paces on the parade ground

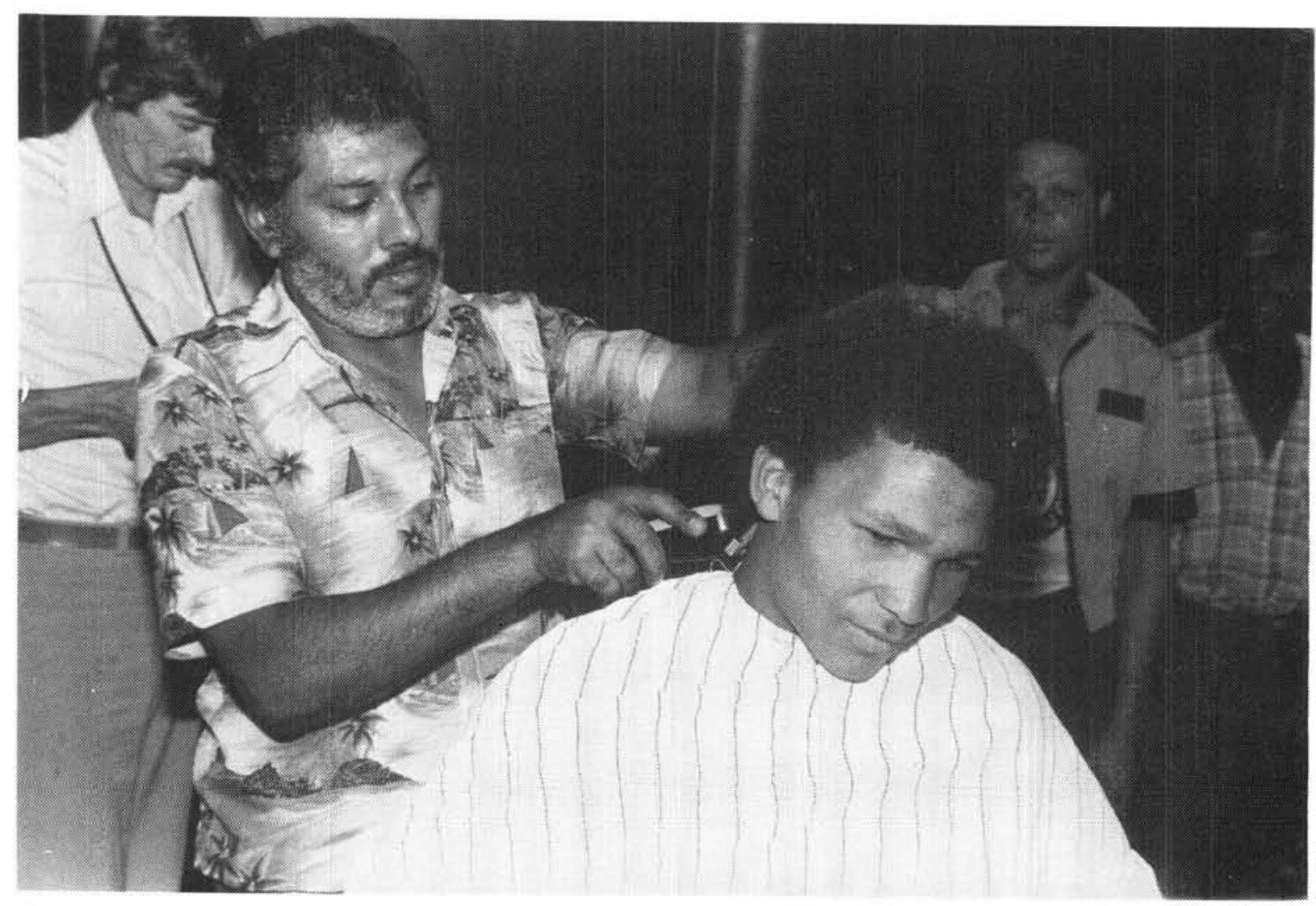

Before the training begins, everyone has to go for a hair cut. The member in the background is looking very worried about his wealth of hair that is shortly going to be something of the past 
enjoy the same medical benefits as their white counterparts.

Coloured volunteers were accepted for 12 months training as infantrymen in 1976 and in the current phase of military operations the Corps has acquired the substantial status of a fully-fledged fighting unit which has, in tours of duty in the Operational Area of SWA/Namibia, displayed a high standard of efficiency, discipline and military élan.

1980 will be remembered as a very significant year for the SA Cape Corps as three new units, namely their own Cape Corps School, a fullyfledged infantry battalion and a maintenance unit were established at Eersterivier. During this time the training period of voluntary National Servicemen was extended from 12 to 24 months.
The SA Cape Corps was the first Non-White unit in the South African Defence Force from whose rank and file emerged members who qualified for appointment to commissioned rank. The first group received their commissions in 1975 and in 1980 a number had progressed to the rank of Major. At present there is an established cadre of Coloured officers in the South African Defence Force holding ranks from junior officers to that of Commandant. A number who have already completed the two year service and have been retained at their own request for an indefinite period, serve in the Commandos and Citizen Force.

It is interesting to note that the majority of this contingency have specifically applied for active service in the Operational Area.

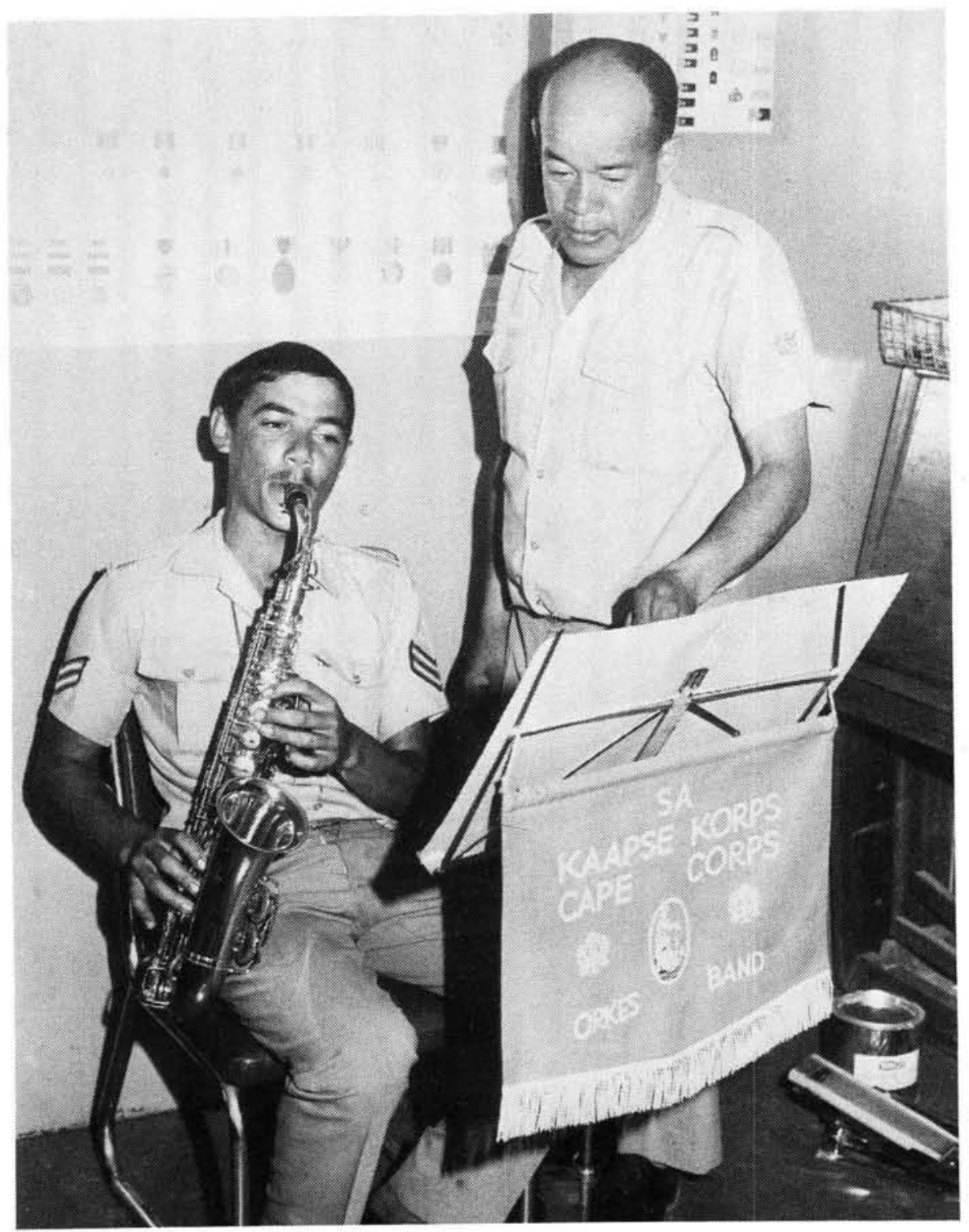

Members of the Cape Corps orchestra preparing for a performance 


\section{SA Navy}

The SA Navy first began recruiting Coloured seamen in 1963. So successful has this recruiting campaign been that it was stepped up in subsequent years and Coloureds are now employed in various posts throughout the Navy inter alia as personnel clerks, storemen, stewards, marines, military police and chefs. They also form part of the crews of strike craft and other surface vessels - in one particular instance Coloured personnel make up 31 per cent of the total staff complement. Between 1982 and 1983 the number of Coloured commissioned officers and other ranks in the SA Navy increased significantly and at this stage Coloureds (all ranks) comprise numerically about 18 per cent of Navy personnel.
Following a decision that Coloureds could also join the South African Air Force, the first batch of 25 men were transferred from the Cape Corps to the Air Force in January 1977 to be trained as ground personnel. Trained personnel include inter alia firemen, intelligence staff, technical and administrative clerks, drivers, chefs, store clerks, bricklayers and carpenters.

A number of Coloureds are employed in the South African Medical Service as clerks in the personnel and logistic divisions.

Coloureds make up 9,5 per cent of the Permanent Force strength, and 16,5 per cent of civilian female workers in the SADF are Coloured.

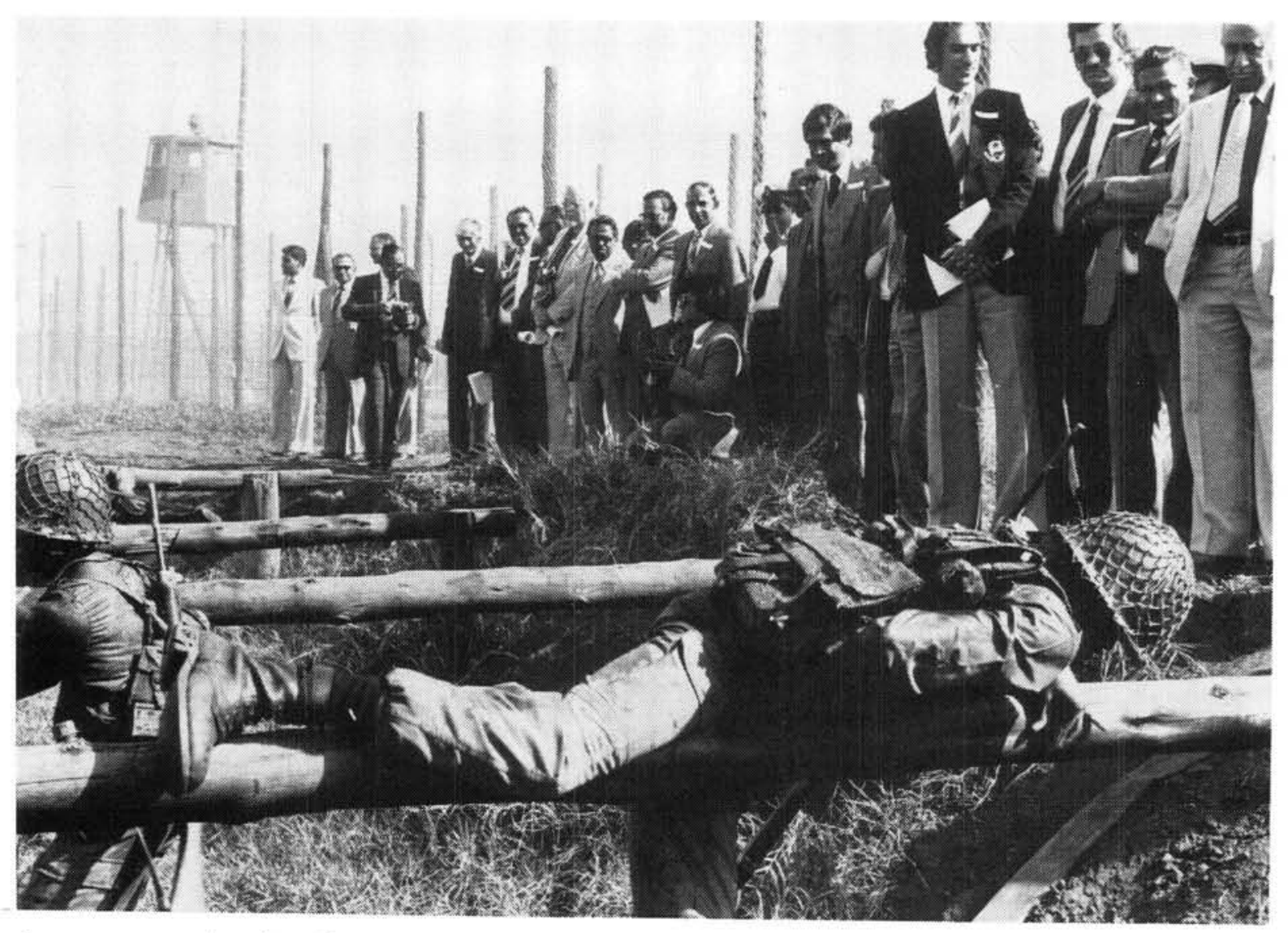

As many men and much equipment as poss/ble are used to make it possible to negotiate an obstacle in the given time 


\section{Indians}

The incorporation of Coloured volunteers into the SADF paved the way for the establishment of a SA Indian Training Battalion on 15 January 1975. Re-designated SAS JALSENA in 1979, the establishment of the unit came about after representation had been made by the Indian Council and other Indian bodies for the creation of a training corps unit manned by Indian South Africans.

As in the case of the SA Cape Corps, Indian candidates were accepted for the SA Navy's Candidate Officers' course in 1977, and in 1978 the first Indian midshipman qualified for appointment to commissioned rank. Under a new system which commenced in 1980, the training period lasts 24 months, eleven of which are spent at SAS JALSENA. Although the initial enlistment takes place on a voluntary basis, approximately 95 per cent apply to join the Permanent Force on completion of their basic training. Most of the instructors at SAS JALSENA are Indians, and trainees go through an exacting course in seamanship, ships' recognition, physical training, rifle drill and related disciplines.
Trainees who have the necessary educational standard and who have proved their leadership potential during training, may be selected as officer candidates and be sent to the SA Naval College, Gordon's Bay for officer training. The present scope of employment for Indian Servicemen in the Permanent Force includes inter alia gunners (Navy), policemen (dog handlers), stewards, chefs, drivers, clerks, divers, hydrographic surveyors and shipwrights.

Between 1982 and 1983 the number of Indians (other ranks) in the South African Navy showed a significant increase of almost 23 per cent. In December 1983 a number of Indians held commissioned ranks in the Navy. A restricted number of Indians are employed in the South African Army, Air Force and Medical Service.

\section{SA Army: Training of Blacks}

In November 1973, the establishment of a training centre for Blacks was authorized by the Chief of the Army. On 21 January 1974 the unit was activated when 16 volunteers presented themselves for basic training at the Prisons Services Training College at Baviaanspoort near

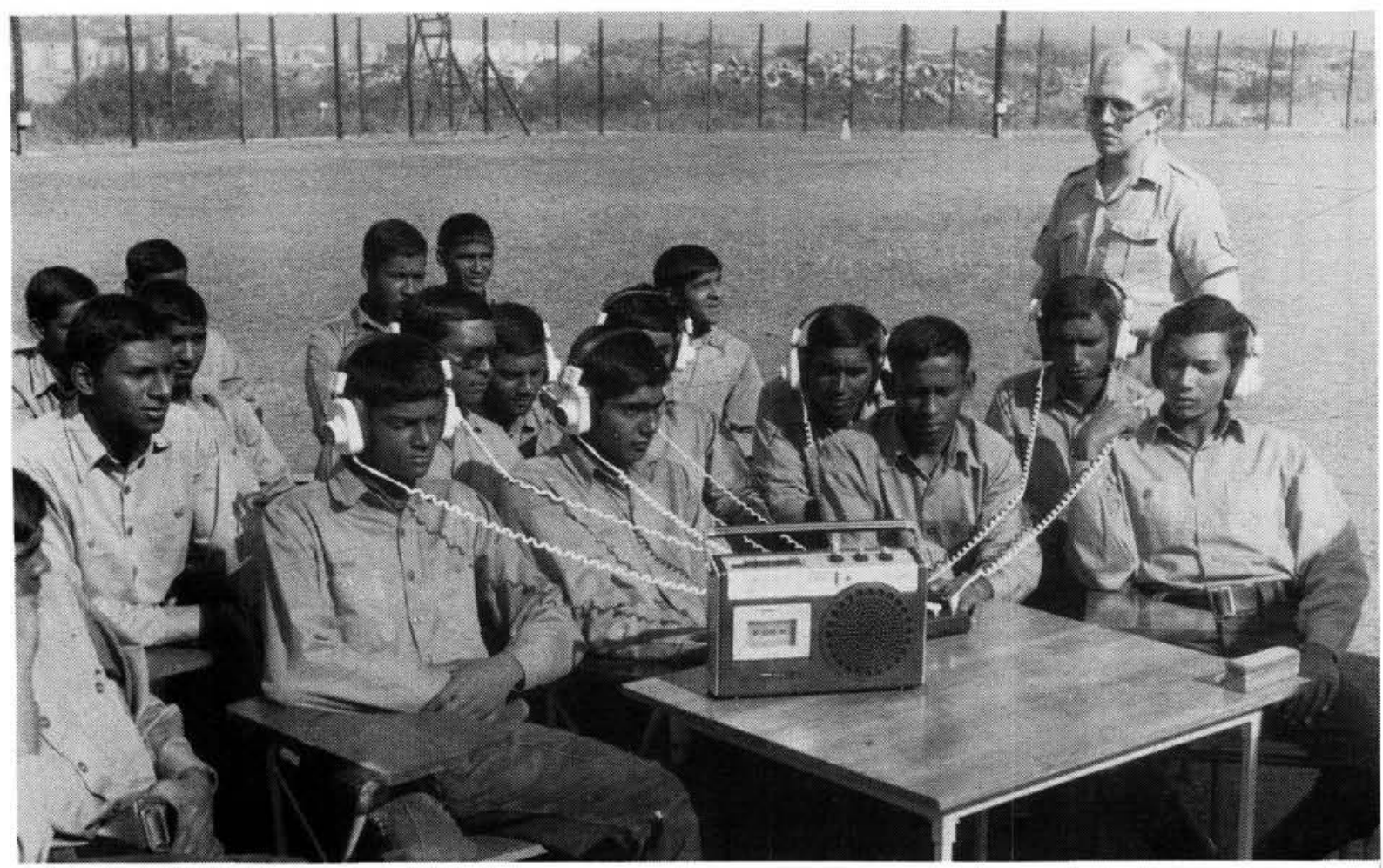

All the Indlan members undergo a course in radlo communication 


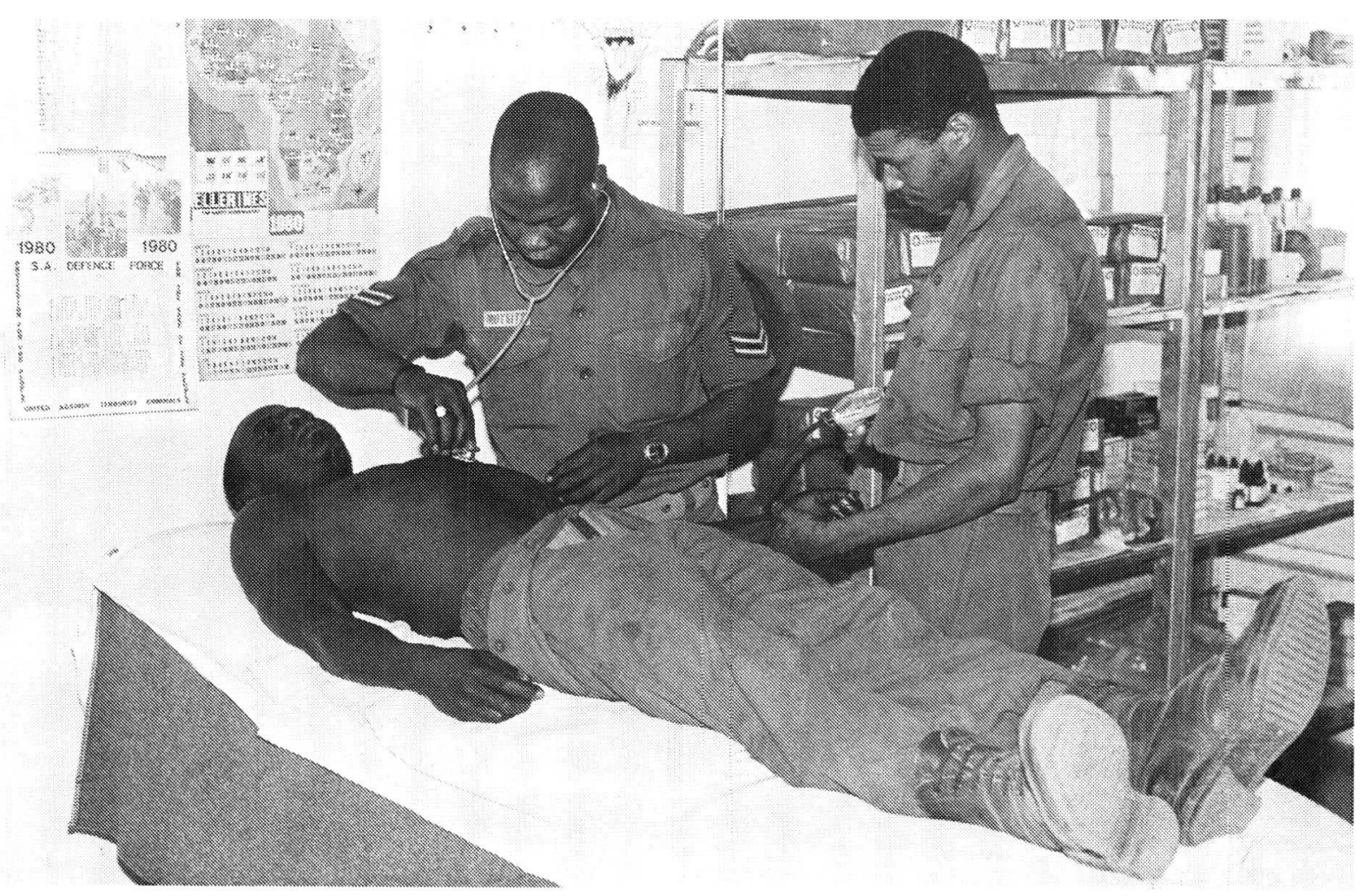

A good soldier must be healthy. Before training can begin, the men undergo a medical examination

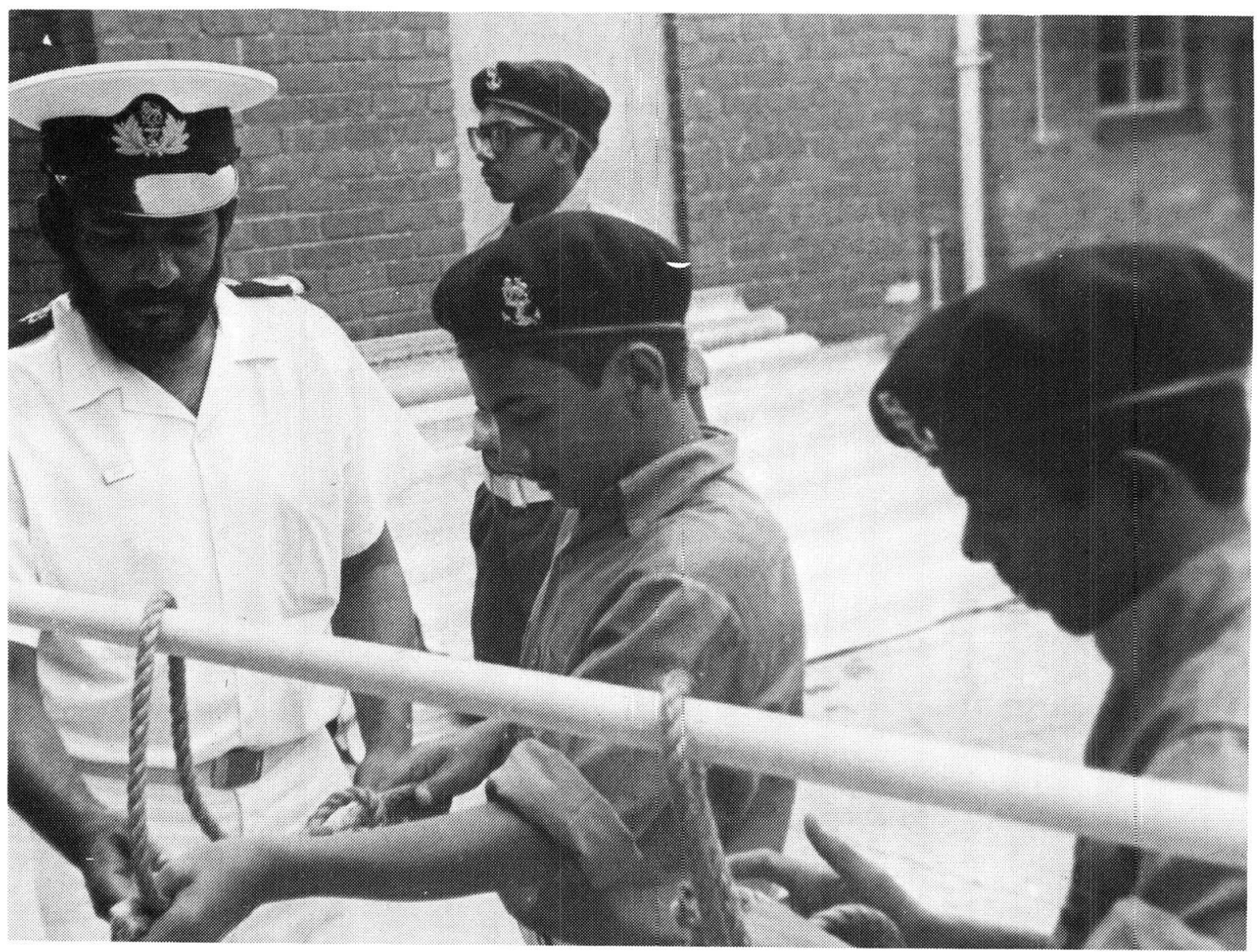

The members learn how to tie knots in a record time 
Pretoria. Originally these men were to be trained as security guards, but after a second intake of 38 members in August 1974, it was decided that the first group should receive advanced training as regimental instructors.

By 1975 Baviaanspoort became the training base for the school. On 4 April that year, the first Black soldiers attested as Permanent Force members of the SADF.

On 1 December 1975 the training group was moved to Lenz, south of Johannesburg, and it was also decided to name this new infantry unit 21 Battalion. The first Black Permanent Force members were promoted to corporal soon afterwards.

In 1975, 21 Battalion assisted in the training of 1 Transkei Battalion. Subsequently other Black units such as the Bophuthatswana National Guard and members of various regional battalions activated in SWA/Namibia have also undergone training under the auspices of the highly qualified instructional cadre at 21 Battalion.

In 1977 the Chief of the Army authorised the training of a company of 21 Battalion for operational duty and in 1978 it left to perform active service in the Operational Area. They acquitted themselves of their task with great distinction. A second company was then trained for operational duty; it proceeded to SWA/Namibia in 1979. In that year, a number of Black Permanent Force members were promoted to the rank of sergeant after having completed qualifying courses at the Services School, Pretoria and at Lenz. These courses are on a par with those attended by White candidates and include instruction in advanced administration and instructors' courses and an orchestration course for members of the band.

At this stage infantrymen form the largest component of black personnel in the South African Army although Blacks are employed in a number of other musterings.

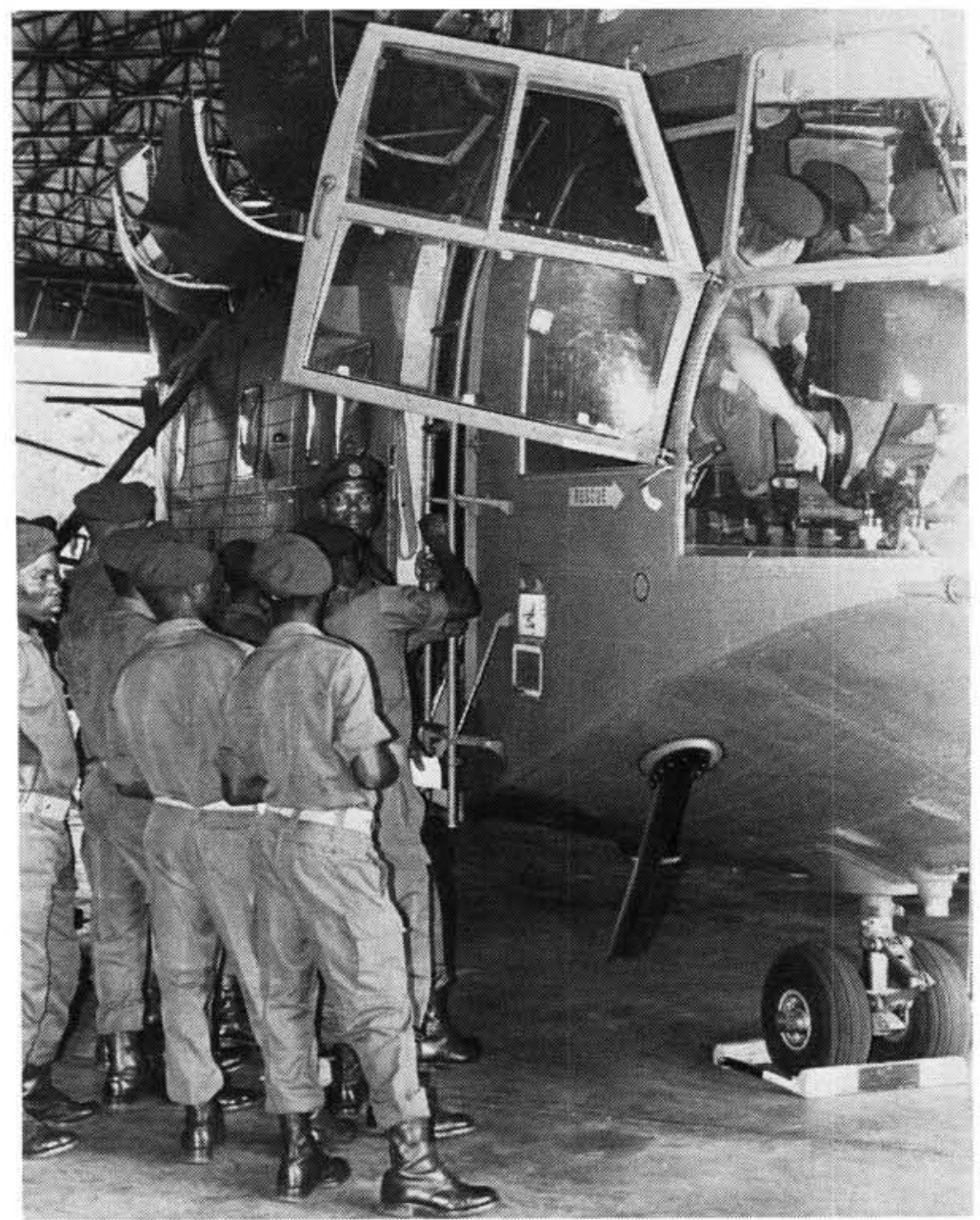

21 Battalion looking at a Frelon helicopter 


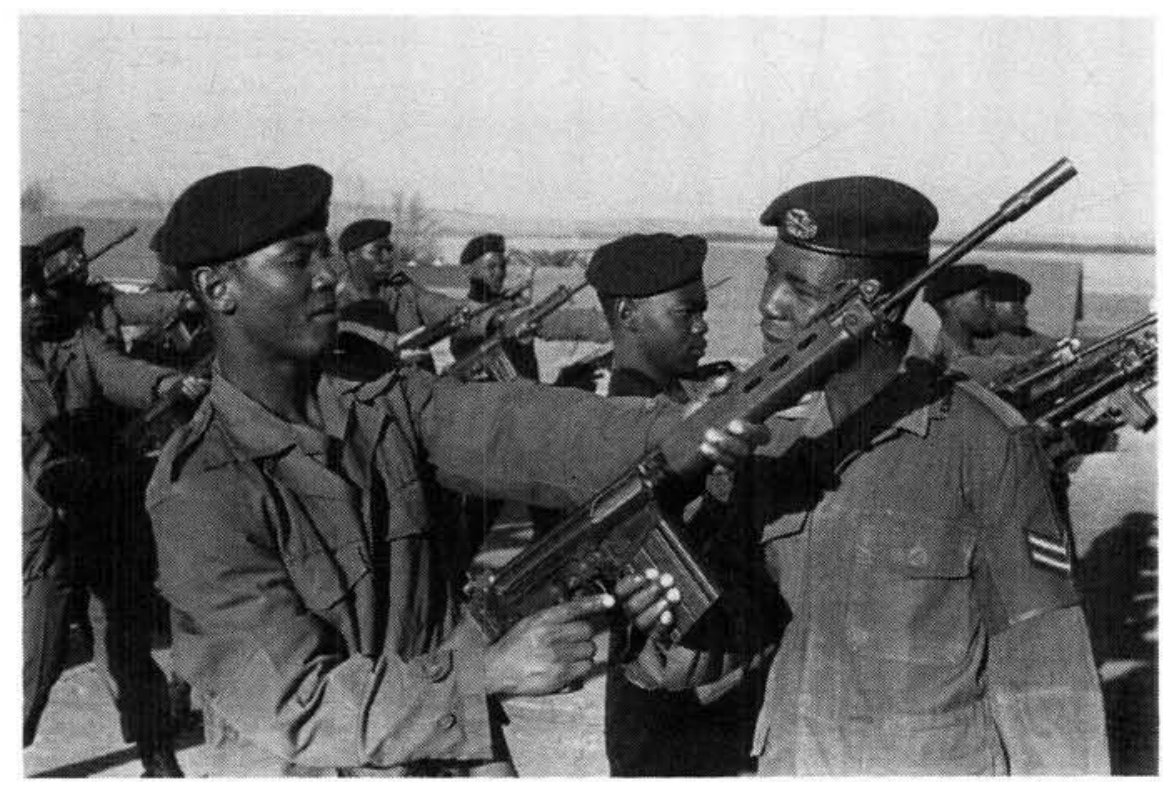

Black members of the SADF busy with weapon-training

During 1982 the training took place with the for. mation of five wings namely a regimental wing, a service wing, an infantry wing, a counter-insurgency wing and, a catering wing. During 1982 $21 \mathrm{Bn}$ also received their unit flag. One of the highlights of 1984 was when they received the Freedom of Soweto. The highlight of 1984 was when the first two Black officers of $21 \mathrm{Bn}$ were commissioned with the rank of Lieutenant. The prime function of $21 \mathrm{Bn}$ is to train Black soldiers for the SA Defence Force and for the National States.

In $198521 \mathrm{Bn}$ turned 11 years old. It has developed into a self-sufficient and disciplined Black training unit. In the same year 5 Black members of the SADF (PF) succesfully completed a course to qualify for commissioned rank.

Members of $21 \mathrm{Bn}$ serve inter alia in the Infantry Corps, the Ordnance Service Corps, the Personnel Service Corps, the Corps of Musicians, the Corps of Military Police and the Finance Service Corps. In accordance with agreements between the Black National States and the Republic of South Africa, the Minister of Defence has approved the formation of Black regional units. Subsequently the training of Black soldiers was started at Amsterdam in the Eastern Transvaal
(111 Battalion, consisting of Swazi soldiers from Kangwane); at Madimbo in Northern Transvaal (112 Battalion, consisting of Vendas from Venda); at Phalaborwa in the Eastern Transvaal (113 Battalion, consisting of Shangaan soldiers from Gazankulu); and at Jozini in Northern Natal (121 Battalion, consisting of Zulus from KwaZulu). A start has also been made with the training of 115 Battalion, designated for KwaNdebele. In the course of 1982, 112 Battalion was transferred to Venda and this unit subsequently became the nucleus of that country's Defence Force.

Unlike the Army, facilities to train Blacks in the Air Force, Navy and Medical Service are still limited.

It should be noted that a number of Blacks are employed in the Auxiliary Service. Like the other staff members of their particular arm of service, they are issued with rations, uniforms and protective clothing. In the Navy for instance, Black members of the Auxiliary Force are responsible for berthing ships, and other duties in the harbour area of Simons Town.

* Cmdt C.J. Nöthling MA is attached to the Military Information Bureau of the SA Defence Force.

- Mrs Lerinda Steyn BA(Comm) $1 \mathrm{~V}$ is attached to the Military Information Bureau of the SA Defence Force. 